\title{
Correction to: Grapevine wood microbiome analysis identifies key fungal pathogens and potential interactions with the bacterial community implicated in grapevine trunk disease appearance
}

Fotios Bekris ${ }^{1}$, Sotirios Vasileiadis ${ }^{1}$, Elena Papadopoulou' ${ }^{1}$ Anastasios Samaras ${ }^{2}$, Stefanos Testempasis², Danae Gkizi ${ }^{3}$, Georgia Tavlaki ${ }^{4}$, Aliki Tzima ${ }^{3}$, Epaminondas Paplomatas ${ }^{3}$, Emmanuel Markakis ${ }^{4}$, George Karaoglanidis ${ }^{2}$, Kalliope K. Papadopoulou ${ }^{1}$ and Dimitrios G. Karpouzas ${ }^{1 *}$ (D)

\section{Correction to: Environmental Microbiome (2021) 16:23} https://doi.org/10.1186/s40793-021-00390-1

Following publication of the article [1], the authors flagged that each author's first and last names had been erroneously swapped in the author list.

The author list has been corrected in the published article and the correct author list may be found in this erratum

\section{Publisher's Note}

Springer Nature remains neutral with regard to jurisdictional claims in published maps and institutional affiliations.

\begin{abstract}
Author details
'Laboratory of Plant and Environmental Biotechnology, Viopolis, Department of Biochemistry and Biotechnology, University of Thessaly, 41500 Larissa, Greece. ${ }^{2}$ Plant Pathology Laboratory, Faculty of Agriculture, Aristotle University of Thessaloniki, Thessaloniki, Greece. ${ }^{3}$ Laboratory of Plant Pathology, Agricultural University of Athens, lera Odos 75, 11855 Athens, Greece. ${ }^{4}$ Laboratory of Mycology, Department of Viticulture, Vegetable Crops, Floriculture and Plant Protection, Institute of Olive Tree, Subtropical Crops and Viticulture, Hellenic Agricultural Organization DIMITRA, 32A Kastorias Street, Mesa Katsabas, 71307 Heraklion, Crete, Greece.
\end{abstract}

Published online: 07 March 2022

The original article can be found online at https://doi.org/10.1186/s40793021-00390-1

\footnotetext{
*Correspondence: dkarpouzas@uth.gr; dkarpouzas@bio.uth.gr

${ }^{1}$ Laboratory of Plant and Environmental Biotechnology, Viopolis,

Department of Biochemistry and Biotechnology, University of Thessaly,

41500 Larissa, Greece

Full list of author information is available at the end of the article
}

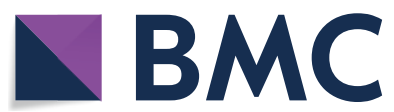

(c) The Author(s) 2022. Open Access This article is licensed under a Creative Commons Attribution 4.0 International License, which permits use, sharing, adaptation, distribution and reproduction in any medium or format, as long as you give appropriate credit to the original author(s) and the source, provide a link to the Creative Commons licence, and indicate if changes were made. The images or other third party material in this article are included in the article's Creative Commons licence, unless indicated otherwise in a credit line to the material. If material is not included in the article's Creative Commons licence and your intended use is not permitted by statutory regulation or exceeds the permitted use, you will need to obtain permission directly from the copyright holder. To view a copy of this licence, visit http://creativecommons.org/licenses/by/4.0/. The Creative Commons Public Domain Dedication waiver (http://creativecommons.org/publicdomain/zero/1.0/) applies to the data made available in this article, unless otherwise stated in a credit line to the data. 